\title{
Phytochemical and Proximate Compositions of Tetracarpidium Conophorum [African Walnut] Seeds
}

\author{
Chikezie, Uchechukwu Nkeirukayvonne \\ Lecturer, Department of Biotechnology, Federal University of Technology Owerri, Imo State, Nigeria
}

*Corresponding Author: Chikezie, Uchechukwu Nkeirukayvonne, Lecturer, Department of Biotechnology, Federal University of Technology Owerri, Imo State, Nigeria

\begin{abstract}
A sample of boiled Tetracarpidium conophorum (African walnut) seeds was analyzed for the phytochemical and proximate compositions. The result of the phytochemical [qualitative] screeningrevealed the presence of high concentrations of Alkaloids and Steroids, and moderate concentration of Tannins. There were no traces of Saponins, Phlobotannins, Flavonoids, Phenols and Glycosides. The proximate analysis showed that the boiled seeds contained 5.5\% moisture, $19.3 \%$ carbohydrate, $17.9 \%$ protein, $53.4 \%$ crude fat, $1.24 \%$ crude fiberand $2.67 \%$ ash. Data from this study showed that the boiled Tetracarpidium conophorum seeds contain some bioactive compounds and have good nutritional composition. They could be useful in pharmaceutical formulations and as food.
\end{abstract}

Keywords: Boiled Tetracarpidium conophorum seeds, Phytochemical screening, Proximate analysis, Bioactive compounds, Food nutrients.

\section{INTRODUCTION}

The plant, Tetracarpidium conophorum (Mull. Arg) Hutch \& Dalziel Syn. Plukenetia conophora, commonly called African Walnut, belongs to the family Euphorbiaceae [GRIN, 2010] and the genus Plukenetia. It is also called Nigerian walnut, Black walnut or Conophor. Tetracarpidium conophorumis a perennial climbing shrub, $10-20 \mathrm{ft}$ long, often found in most forest zones of sub Saharan Africa. It is not related to the walnut, being so named because its nuts bear a superficial resemblance to the walnut. Tetracarpidium conophorumis native to tropical western and central Africa, from Togo to Congo and in Sierra Leone, and is abundant in Nigeria, Cameroon, Republic of the Congo and the Democratic Republic of Congo. It prefers rain forest hedge in half-shady places; low bush; secondary forest; plantations at elevations from 250-1,400 m (820-4,590 ft), and produces stems usually 3-15 m (9.8-49.2 ft) long, though they can be up to $30 \mathrm{~m}$ (98 ft) long[Wikipedia, 2016].Black walnut grows best on moist, deep, fertile, well drained loamy soils, although it also grows quite well on silty clay, loam soils [ Williams, 1990; Cogliastro et al., 1997]. It is a lightdemanding specie, requiring full sun to grow well [Brinkman, 1974].

Tetracarpidium conophorum is known in southern Nigeria as "ukpa" [Igbo], in western Nigeria as "awusa" or "asala" [Yoruba] and is known as "kaso" or ngak" in the littoral and western Cameroun [Dalziel, 1937]. It is known in northern Nigeria as"gawudi bairi”[Hausa].In Nigeria, Tetracarpidium conophorumis found in Lagos, Uyo, Akamkpa, Akpabuyo, Kogi, Ajawa -Ogbomoso and Ibadan [Ayoola et. al., 2011]. Theplant is cultivated principally for the nuts which are cooked and consumed as snacks [Oke, 1995]. The nut is an excellent source of protein and provides high food energy value [Nwaoguikpe et al., 2012; Ojobor et al., 2015].The seed/nut is thin-shelled and about $25 \mathrm{~mm}$ (0.98 in) long.It is contained in a pod which may house one-shelled nut [single], two-shelled nut [double] and three-shelled nut. The walnut shells could be black or brown from the plant. Thenut is whitish upon cracking from the shell. The nut has a thin layer in between two halves. [Ayoola et al., 2011]. The seeds take 4-6months to mature and are found in the local market between the months of June and September. In Nigeria, it is traditionally eaten as nut after boiling [Akpuaka and Nwankwo, 2000].

Walnuts are shown to decrease endothelial dysfunction associated with high fat diets [Anderson et al., 2001].A study has suggested that consumption of walnut increases fat oxidation and reduces carbohydrate oxidation without affecting total consumption, suggesting that walnut consumption may 
improve the use of body lipids in overweight adults. Walnut is useful in treating Rheumatism, gout, cold, kidney pain, heavy menstrual bleeding, as a blood cleanser and to expel worms [Ekhuosuehi, 2008]. It is believed to stop asthma and is prescribed to be taken between bouts of asthma but not for acute asthma. It is used for the elderly as a constipation cure [Wikipedia, 2009]. The young leaves and shoots are edible vegetable. The leaf is useful in the treatment of cancers that grow in the neck region.They are usedas tea for diarrhea, gastro-intestinal system and inflammation of the gums, mouth and throat. The root is especially good in treating piles. The bark is used in tea as laxative and chewed for toothache. It helps to prevent and control high blood pressure [Ekhuosuehi, 2008]. The oil from the nut has been used in the formulation of wood varnish, stand oil, vulcanized oil for rubber and leather substitutes. [Babalola, 2011].Walnut shell is compatible with other materials and work well as filler in dynamite. The shell is ideal as the gritty, rough agent in soap, cosmetics and dental cleaner [Ekhuosuehi, 2008].The shells are used as fuel in co-generation power plants and in oil-well drilling, as well as in the paint industry for making paints and varnishes.

Nwokolo [1987] reported on the impact of traditional processing on the nutrient and sensory qualities of the nut. Oke and Fafunsho [1995] studied the high nutrient potentials of the nut. Oyenuga [1997] reported the amino acid and fatty acid components of the nuts, and the use of its leaf juice for the treatment of prolonged and constant hiccups. Okpero [2001] reported on the methods of processing the Tetracarpidum conophorum nuts. Ayodele [2003] reported the presence of oxalates, phylates and tannin in the raw Tetracarpidium conophorum nuts. The proximate composition, ascorbic acid and heavy metal content of the nut were reported by Edemet al., [2009]. The effects of different methods of extraction of the walnut seeds on phytochemical constituents and on antimicrobial activities was reported by Malu et al., [2009]. Obianime and Uche [2010] reported the effects of aqueous extracts of the seeds of Tetracarpidium conophorum on hormonal parameters of male guinea pig. Oselebe et al., [2010] studied the physiochemical and pasting characteristics of defatted and undefattedflours derived from African Walnut [Tetracarpidium conoforum]. Amaeze et al., [2011] evaluated the antioxidant activity of Tetracarpidium conophorum (Mull. Arg) Hutch \& Dalziel leaves. The root of Tetracarpidium conophorum was reported to be a potential source of useful drug formulation due to the fact that it contains important bioactive components [Ayoola et al ., 2011].Bello et al., [2013] screened for the antimicrobial qualities of walnut [Tetracarpidum conophorum Mull. Arg] leaf and onion bulb [Allium cepa Linn.] extracts against six pathogenic bacteria of fish.

Ayoolaet al., [2011] evaluated the chemical and nutritive values of Tetracarpidium conophorum seeds in their locality. As yet, not much studies has been carried out on the boiled Tetracarpidium conophorum seeds. This research studied the phytochemical and proximate compositions of boiled Tetracarpidium conophorum seeds found in the locality of this study, in order to evaluate its usefulness in pharmaceutical formulations and as food.

\section{MATERIALS AND METHODS}

\subsection{Sample Preparation}

The boiled nuts were purchased from Ekeonuwa market, Owerri, in Imo State, Nigeria. The shells were removed and the nuts air-dried for seven days before milling to a coarse powder. The coarse powder was stored in an air-tight container prior to analyses.

\subsection{Phytochemical Analysis}

Phytochemical screening was done using the methods described by Ogukweet al., [2004] and Yadav and Agarwala [2011].

\subsection{Proximate Analysis}

Protein content was determined by Kjeldahl method and ash content by ignition at $550^{\circ} \mathrm{C}$ in a muffle furnace for four hours. Moisturecontent was determined by drying to constant weight at $105^{\circ} \mathrm{C}$ in an oven. The crude fat content was determined by Soxhlet extraction with petroleum ether as solvent, and crude fibre content by the acid and alkaline digestive methods [AOAC,1990]. The carbohydrate content was estimated by differences, subtracting the sum of water, protein, fat, crude fiberand ash percentages from one hundred.

\section{RESUlts}

The result of the phytochemical [qualitative] screening of the boiled Tetracarpidium conophorum seeds is presented in Table 1. It shows that the seeds contain high concentrations of alkaloids and 
steroids, while tannins were present in moderate quantity. There were no traces of Saponins, Flavonoids, Phenols, Phlobotannins and Glycosides.

The result of the proximate analysis of boiled Tetracarpidium conophorum seeds, as presented in Table 2 shows that the boiled seeds have high crude fat content [53.4\%] and moderate quantities of carbohydrate [19.28\%] and crude protein [17.9\%]. This result is within the range reported by Ogunsma and Ddeboma [1983] and Osogie et al., [1986]. The seeds also contain crude fibre [1.24\%], crude ash [2.66\%], and moisture [5.46\%] [Table 2].

Table1. Phytochemical composition [qualitative] of boiled Tetracarpidium conophorumseeds

\begin{tabular}{|l|l|}
\hline Constituents. & Bioassay. \\
\hline Saponins & - \\
\hline Flavonoids & - \\
\hline Steroids & ++ \\
\hline Phenol & - \\
\hline Alkaloids & ++ \\
\hline Tannins & + \\
\hline Phlobatannins & - \\
\hline Glycosides & - \\
\hline
\end{tabular}

Key: + = Present in moderate amount.

$$
\begin{aligned}
& ++=\text { Present in high amount. } \\
& -=\text { No tracel not detected. }
\end{aligned}
$$

Table2. Proximate composition of boiled Tetracarpidium conophorum seeds

\begin{tabular}{|l|l|}
\hline Constituents. & Composition [\%]. \\
\hline Crude protein content & 17.90 \\
\hline Crude fat content & 53.74 \\
\hline Carbohydrate content & 19.28 \\
\hline Moisture content & 5.46 \\
\hline Crude fiber content & 1.24 \\
\hline Ash content & 2.66 \\
\hline
\end{tabular}

\section{DISCUSSION}

Phytochemicals are biologically active compounds, found in trace amounts, which are not established nutrients, but which nevertheless contribute significantly to protection against degenerative diseases [Dreosti, 2000]. The result of the phytochemical [qualitative] screening of the boiled Tetracarpidium conophorum seeds shows that the seeds contain high concentrations of alkaloids and steroids, and also contain moderate quantity of tannins. Nwaoguikpe et al., [2012] and Ojobor et al., [2015] also reported the presence of alkaloids and tannins in the phytochemical analysis of raw Tetracarpidium conophorum seed samples.

Alkaloids have been associated with medicinal uses for centuries, and oneof their common biological propertiesis their cytotoxicity [Nabori, et al., 1994]. Several workers have reported the analgesic [Antherden, 1969], antispasmodic and antibacterial [Stray, 1998] properties of alkaloids. This is why the seed is believed to stop asthma and is prescribed to be taken between bouts of asthma, but not for acute asthma. It is also used for the elderly as a constipation cure [Wikipedia, 2009]. Alkaloids have been implicated for its detoxifying and antihypertensive properties [Trease and Evans, 1989].

The presence of tannins in the boiled seeds of Tetracarpidium conophorum supports its anti inflammatory properties and its use for healing haemorrhoids, frost bite and varicose ulcers in herbal medicine [Igboko, 1983; Maduiyi, 1983]. The presence of tannins suggest the ability of this plant to play a role as antidiarrhoeic and antihaemorrhagic agent. [Asquith and Butler, 1986]. Parekh and Chanda [2007] reported that tannins are known to react with proteins to provide the typical tanning effect which is important for the treatment of inflamed or ulcerated tissues. Tannins bind to proline rich protein and interfere with protein synthesis. Herbs that have tannins as their main components are astringent in nature and are used for treating intestinal disorders such as diarrhea and dysentery [Dharmananda, 2003]. 
The result also shows that the boiled seeds contain high quantities of steroids. Steroids have been reported to have antibacterial properties [Raquel, 2007], and they are very important compounds especially due to their relationship with compounds such as sex hormones [Okwu, 2001]. Ajaiyeoba and Fadare [2006] reported that the nut has been shown to cure male infertility problems. Some plant steroids are also useful for their effects when consumed by human beings, because their presence decreases the amount of cholesterol in the blood stream. [Wisegeek, 2013].

In all, the result of phytochemical screening obtained suggests that the identified phytochemical compounds present in the boiled Tetracarpidium conophorum seeds could be the bioactive compounds that confer medicinal qualities to the seeds. These observations support the use of Tetracarpidium conophorum seeds in herbal cure remedies or traditional medicines.

The proximate analysis of the boiled Tetracarpidium conophorum seeds shows that the seeds have moderate quantities of carbohydrate [19.28\%] and crude protein [17.90\%], and high crude fat [53.4\%] content. The seeds also contain crudefiber [1.24\%], crude ash [2.66\%], and moisture [5.46\%]. Therefore the seedshave good nutritional value. The main nutritional value of legumes lies in their supply of cheap, dietary protein and calories in the developing countries of the world [USNAs, 1980]. Therefore, Tetracarpidium conophorum seeds could play a role, considering its crude protein [17.9\%] and carbohydrate [19.28\%] contents. The high crude fat content [53.74\%] of the boiled seed suggests its exploitation as an oil seed. In this regard, it has been used for the generation of dry oil. [Akpuaka and Nwankwo, 2000; Tchiegang, 2001].

Ayoola et al., [2011] reported the presence of vitamins, such as ascorbic acid [4.15mg/100g], tocopherol [122.57mg/100mg], and trace amounts of Vitamins $B_{1}, B_{2}, B_{3}$, and $B_{12}$, on a dry weight basis in the raw seeds of Tetracarpidium conophorum seeds.

Ascorbic acid [Vitamin C] is an antioxidant and helps to protect healthy cells from damage caused by free radicals. It helps in absorption of iron, promotes wound healing and also helps the body's immune system. The presence of ascorbic acid in the seed supports the use of the plant in herbal medicine for the treatment of skin conditions, including eczema, pruritus, psoriasis and parasitic conditions [D'Amelio, 1999]. This vitamin can also be used for the treatment of common cold and other diseases like prostrate cancer [Okwu and Okwu, 2004; Okwu and Okeke, 2003]. There is also an interesting ability of ascorbic acid as an antioxidant to prevent, or at least minimize the formation of carcinogenic substances from dietary material [Hunt et al., 1980].

Tocopherol [Vitamin E], also an antioxidant, protects the body from the damage of oxidation. It is important in the formation of red blood cells and the use of vitamin K [blood-clotting vitamin]. Deficiency of to copherol causes sterility in animals e.g. rats. The presence of tocopherol in appreciable amount in the Tetracarpidium conophorumseeds supports its use to cure male infertility problems [Ajaiyeoba and Fadare, 2006].

Previous reports[Ayoola et al., 2011], have also shown that the Tetracarpidium conophorum seed contain rich sources of mineral elements, such as; Calcium [4337.5mg/kg], Magnesium [1711.25mg/kg], Potassium [6250.00mg/kg], Sodium [4830.00mg/kg], Iron [110.00mg/kg], Zinc $[40.10 \mathrm{mg} / \mathrm{kg}]$, Manganese $[22.00 \mathrm{mg} / \mathrm{kg}]$, and Copper $[15.45 \mathrm{mg} / \mathrm{kg}]$, which are very useful in the body. The sodium and potassium content of Tetracarpidium conophorum seed is an added advantage, because of the direct relationship of sodium [Na] intake with hypertension in human [Dahl, 1972]]. This may be the reason why the plant is used to prevent and control high blood pressure [James, 2009].The manganese content shows that the plant can be used to protect bone disease[James, 2000]. Manganese is necessary for the functioning of the pituitary gland, the pineal gland and the brain, it promotes hepatorenal function, combats anemia and is also essential for growth [Claude and Paule, 1979].Manganese is used in the management of diabetes [Edemet al., 2009]. The copper content is important for cellular defence and protection of the mucous membrane, is anti-anaemic and is essential for the formation of haemoglobin from iron .The presence of copper maybe responsible for the absorption of iron, it is therefore often seen with iron naturally[Claude and Paule, 1979]. The presence of zinc suggests that the seed may have some effect on the nerve function and male sterility. This supports the use of Tetracarpidium conophorumseeds to cure male infertility problems [Ajaiyeoba and Fadare, 2006]. Zinc is important for normal sexual development, especially for the development of testis and ovaries. It is also essential for reproduction. Zinc stimulates the activity of vitamins, formation of red and white corpuscles [Claude and Paule, 1979]; healthy functioning of the heart and normal growth [Elizabeth, 1994]. 


\section{CONCLUSION}

This study has shown the phytochemical [qualitative], and proximate compositions of boiled Tetracarpidium conophorum seeds. It revealed that the boiled seeds contain high concentrations of alkaloids and steroids, and also contain moderate quantities of tannins. These bioactive compounds could be responsible for the reported medicinal properties of Tetracarpidium conophorum seeds. The study has also shown that the boiled Tetracarpidium conophorum seeds contain moderate quantities of crude protein and carbohydrate, and a high crude fat content. Thus, the seed is a source of cheap dietary protein and calories. The Tetracarpidium conophorum seed also contains some essential vitamins and is a rich source of mineral elements. Therefore, this study reveals that the boiled Tetracarpidium conophorum seeds contain some bioactive compounds and have good nutritional value. They could be useful in pharmaceutical formulations and as food. Its high crude fat content suggests exploitation as an oil seed. Further studies should be carried out to isolate, characterize and elucidate the structures of the bioactive compounds contained in the boiled Tetracarpidium conophorum seeds, to elucidate their mechanism of action and use in pharmaceutical formulations.

\section{REFERENCES}

Ajaiyeoba E.O and Fadare.D.A. [2006]Antimicrobial potential of extracts and fractions of the African walnutTetracarpidium conophorum. Afric. Journal of Biotechnology 5[22]:2322-5.

Akpuaka M.U and Nwankwor E. [2000] Extraction, analysis and utilization of a drying-oil from Tetracarpidium conophorum. Bioresource Technology, 73: 195 - 196.

Amaeze O. U, Ayoola G.A, Sofidiya M.O, Adepoju-Bello A.A, Adegoke A.O, and Coker H. A. B [2011]. Evaluation of antioxidant activity of Tetracarpidium conophorum (Mull. Arg) Hutch \& Dalziel. Oxidative Medicine and Cellular Longevity. 976701. Doi: 10.1155/2011/976701.

Anderson K.J, Teuber S.S, Gobeille A, Cremin P,WaterhouseA.L, Steinberg F. M [2001] .Walnut polyphenolics inhibit in vitro human plasma LDL oxidation. Journal ofNutrition,131:2837-84.

Antherden L.M. [1969] Textbook of Pharmaceutical Chemistry, $8^{\text {th }}$ ed. Oxford University Press, London, Pp: $813-814$.

AOAC [1990] StandardOfficial Methods of Analysis of the Association of AnalyticalChemists. $16^{\text {th }}$ Ed. Arlington VA, USA.

Asquith, T.N andButlerL.G. [1986] Interaction of condensed Tannins with selected proteins.Phytochem., 25[7]: $1591-1593$.

Ayodele O.B [2003] Nutrition in Ibadan Nigeria.Catoon Publishers, USA.

Ayoola P.B., Onawumi O.O and O.O.P. Faboya [2011] Chemical evaluation and nutritive values of Tetracarpidiumconophorum [Nigerian walnut] seeds.Journal ofPharmaceutical and Biomedical Sciences. $11[15]: 1-5$.

Babalola, F.D [2011] Cultivation of African walnut Tetracarpidiumconophorum Mull. [Arg] on agricultural plantation:An approach to Conservation Agriculture in Nigeria. Presentation made at World Conference on Conservation Agriculture and $3^{\text {rd }}$ Farming System Design Conference [WCCA/FSD], Brisbane, Australia from 26 - 29 September, 2011. Pp 180 - 181. Available online at http://aciar.gov.au/files/node/13992/ cultivationofafricanwalnuttetrac arpidiumconop86676.pdf Accessed 26 $6^{\text {th }} \mathrm{July}, 2016$.

Bello O. S., Olaifa F.E ., Emikpe B.O., and Ogunbanwo S.T., [2013]. Potentials of walnut [Tetracarpidum conophorum Mull.Arg] leaf and onion [Allium cepa Linn] bulb extracts as antimicrobial agents for fish. African Journal of Microbiology Research. Vol 7 (19): 2027 - 2033.

Brinkman K .A.[1974]. Juglans L. Walnut. In:Schopmeyer CS [tech coord] Seeds of woody plants in the United States, USDA For Serv Agric Handb 450, Washington, pp. 454 - 459.

Cogliastro, A,. Gaganon, D. and Bouchard A., [1997] Experimental determination of soil characteristics optimal for the growth of ten hardwoods planted on abandoned farmland. For Ecol Manage (1- 2): pp.49 63. Goodell, E. [1984] Walnuts for the northeast. Arnoldia , 44 (1): pp. 3 - 19.

Claude B. and Paule S. [1979].The Manual of Natural Living. ${ }^{\text {st }}$ ed. Biddles Limited. Guildford, Surrey. Pp 98 99, 101.

D’Amelio F.S. [1999] Botanical: A Phytocosmetic Desk References. Boca Raton, FL, CRC Press. Pp 209.

Dahl L.K. [1972] Salt and Hypertension.Am, Clin.Nutr.25: 231 - 38.

Dalziel J.M. [1937] the useful plants of West Tropical Africa.Whitefriars Press, London. Pp 164.

Dharmananda .S. [2003] Gallnuts and the uses of Tannins in Chinese Medicine. In: Proceedings of Institute for Traditional Medicine, Portland, Oregon. 
Dreosti I. E [2000] Recommended dietary intake for phytochemicals: Feasible or Fanciful? Asian Pacific Journal of Clinical Nutrition 9: $119-122$.

Edem, Christopher.A. Dosunmi, Miranda I, and Bassey Francesca,I. [2009]. Determination of Proximate Composition,Ascorbic acid and Heavy Metal content of African Walnut [Tetracarpidium conophorum]. Pak .J. Nutrition. 8. $225-226$.

Ekhuosuehi, .A. [2008]. Properties of Walnut plant in culture. The Nigerian Observer Online edition $w w w$. nigerianobservernews.com/19072010/.../features3.html. 12/10/2012. 2.20pm. Accessed $10^{\text {th }}$ June, 2016.

Elizabeth .K. [1994].Textbook on Immense help from Natures workshop. $1^{\text {st }}$ ed. Elikaf Health Services Ltd. Pp 207.

GRIN,[2010]. Plukenetia conophora Müll. Arg.Germplasm Resources Information Network (GRIN) Taxonomy for Plants. United States Department of Agriculture (USDA) and Agricultural Research Services (ARS), Beltsville area.http://www.ars-grin.gov/cgi-bin/npgs/html/taxon.pl? 400342. Accessed 18/08/16.

Hunt S. ,Gaff. J. L., and Holbrook .J. [1980]. Nutrition principles and chemical practices.John Wiley and Sons. New York. Pp $49-52$.

Igboko D.O. [1983].Phytochemical studies on Garcinia kolaHeckel. M.Sc. Thesis. University of Nigeria Nsukka.Pp 202.

James .N.R. [2000]. Volatile components of Green Walnut Husks.J. Agric. Food Chem.48 [7]: 2858 - 61.

Maduiyi .I. [1983].Biochemical and Pharmacological studies of active principles of the seeds of GarciniaKola Heckel M.Sc. Thesis. University of Nigeria Nsukka.Pp 108.

Malu S.P , Obochi G.O, Edem C.A, and Nyong B.E [2009]. Global Journal of Pure and Applied Sciences, 15(3): 373- 376.

Nabori, T., Miurak, K., Wu, D.J., Takabayashik.L.A and CarsonD.A, [1994].Deletion of cyclin-dependent kinase -4 inhibitor gene in multiple human cancers.Nature, 46: 753 - 756.

Nwaoguikpe R.N., Ujowundu, C.O., and Wesley, B. [2012] Phytochemical and Biochemical compositions of African Walnut [Tetracarpidium conophorum]. Journal of Pharmaceutical and Biomedical Sciences. Vol. 20 [09].

Nwokolo E.A. [1987].Composition and Availability of Nutrients in some Tropical Legumes. Phacco Publishers, Ibadan.

Obianime A.W and Uche , F.I.[2010]. The effects of aqueous extracts of Tetracarpidum conophorum seeds on the hormonal parameters of male guinea pigs. Asian Pacific Journal of Tropical Medicine . 21 - 24.

Ogukwe C.E., Oguzie, E.E., C. Unaegbu and Okolue B.N, [2004]. Phytochemical screening on the leave of Sanservieriafasciata.J. of Chem. Soc. Nigeria, 29 [1]: 8 - 9.

Ogunsma A.O and Ddeboma .M.R. [1983]. Chemical Composition of Tetracarpidium conophorum [Conophurint]. Food Chem., 10: 173 - 177.

Ojobor C.C .,Anosike, C.A., and Ani, C.C [2015] Studies on Phytochemical and nutritional properties of Tetracarpidium conophorum [Black walnut] seeds. Journal of Global Biosciences., Vol 4 [2]: 1366 -1372.

Oke, O.L [1995]. Leaf Protein Research in Nigeria. Ibadan. University of IbadanPress. Ibadan.

Oke, O.L and Fafunsho .M.A. [1995]. Lesser known oilseeds: The nutritive value of conophor seeds in vitro. Nutrition Report International. 12: $41-49$.

Okpero, O. [2001] Nutritive value of Conophor seed.University of Ibadan Press. Ibadan.

Okwu, D.E. [2001]. Evaluation of Chemical Composition of Indigenous Species and Flavouring Agents. Global J. Pure Appl. Sci.: 458 - 459.

Okwu, D.E. and Okwu .M.E [2004]. Chemical Composition of Spondiamombin plants. J.Sustain Agric. Environment. 6: $140-147$.

Okwu, D.E. and Okeke.O. [2003]. Phytochemical Screening and Mineral Composition of Chewing sticks in South- Eastern Nigeria. Global J. Pure Appl. Science. 9: 235 - 238.

Onyenuga V.A. [1997]. Nigeria Food and Feeding Stuffs, Ibadan University Press. Pp 1-25.

Oselebe H.O., Nnamani, C.V and NdieE.C [2010]. Some Physiochemical characteristics of defatted flours derived from African walnut Tetracarpidiumconoforum: An underutilized legume. Pakistan Journal of Nutrition 9[9]: $909-911$.

Osogie, A.U., OkoyeW.L ., Oluwagose B.O. and Dowodu O.A. [1986]. Chemical quality parameters and fatty and composition of oils of some underexploited tropical seeds. Nig. J. Applied Sci, 4: 151 - 162.

Parekh .J. andChanda.S. [2007]. Antibacterial and Phytochemical studies on twelve species of Indian Medicinal Plants.Africa .J. Biomed. Res.10: 175 - 181. 
Raquel F.E. [2007]. Bacterial lipid composition and antimicrobial efficacy of cationic Steroid compounds. Biochemicaet Biophysica Acta. 2500 - 2509.

Stray, F. [1998]. The Natural Guide to Medicinal herbs and plants. Tiger Books International London. Pp 12 16.

Tchiegang .C.[2001] Chemical Composition of oil from Tetracarpidium conophorum [M.L. ARG] Hutch and Dalziel] nuts. J. Food Lipids. 8: 95 - 102.

Trease, G.E and EvansW.C. [1989] Pharmacognosy $11^{\text {th }}$ ed. BailliereTindall, London. Pp $45-50$.

US NAs [1980] Dietary Allowance: US National Academy of Science, Washington DC.

Wikipedia [2009]. African Walnutfrom Free Encyclopedia.

Wikipedia [2016] Plukenetia conophora."http://en.wikipedia.org/w/index.php?title=Plukenetia conophora \& old id-73160465". Accessed 20 July, 2016.

William, R. D., [1990]. Juglans nigra L.,Black walnut. In: Burns RN, Honkala BH [tech coords] Silvics of North America, Vol 2. Hardwoods. USDA For Serv Agric Handb 654, Washington, pp 386 - 390.

Wisegeek [2013] Whatare plant steroids.www.wisegeek.com/what-are-plant-steriods.htm. Accessed 29th October, 2013.

Yadav, R.N.S and Agarwala.M. [2011] Phytochemical analysis of some medicinal plants. Journal of Phytology3 [12]: $10-1$.

Citation: C. Uchechukwu Nkeirukayvonne, "Phytochemical and Proximate Compositions of Tetracarpidium Conophorum [African Walnut] Seeds", International Journal of Research Studies in Biosciences (IJRSB), vol. 5, no. 10, pp. 25-31, 2017. http://dx.doi.org/10.20431/2349-0365.0510005

Copyright: () 2017 Authors. This is an open-access article distributed under the terms of the Creative Commons Attribution License, which permits unrestricted use, distribution, and reproduction in any medium, provided the original author and source are credited. 